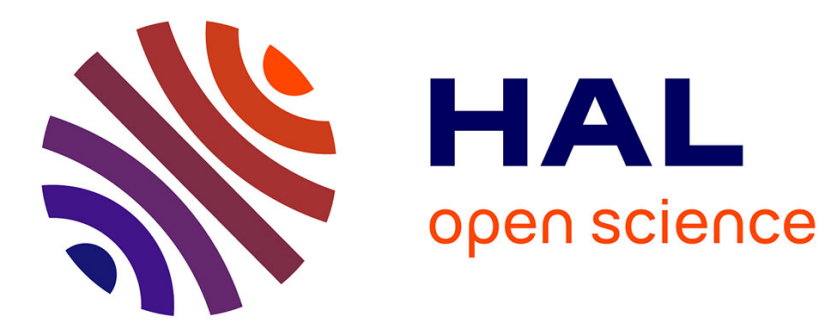

\title{
Mobilization of neutrophils and defense of the bovine mammary gland
}

\author{
Pascal Rainard, Céline Riollet
}

\section{To cite this version:}

Pascal Rainard, Céline Riollet. Mobilization of neutrophils and defense of the bovine mammary gland. Reproduction Nutrition Development, 2003, 43 (5), pp.439-457. 10.1051/rnd:2003031 . hal-00900520

\section{HAL Id: hal-00900520 \\ https://hal.science/hal-00900520}

Submitted on 1 Jan 2003

HAL is a multi-disciplinary open access archive for the deposit and dissemination of scientific research documents, whether they are published or not. The documents may come from teaching and research institutions in France or abroad, or from public or private research centers.
L'archive ouverte pluridisciplinaire HAL, est destinée au dépôt et à la diffusion de documents scientifiques de niveau recherche, publiés ou non, émanant des établissements d'enseignement et de recherche français ou étrangers, des laboratoires publics ou privés. 


\title{
Review
}

\section{Mobilization of neutrophils and defense of the bovine mammary gland}

\author{
Pascal RAINARD*, Céline RIOLLET
}

\author{
Laboratoire de Pathologie Infectieuse et Immunologie, \\ Institut National de la recherche Agronomique, 37380 Nouzilly, France
}

\begin{abstract}
The leucocytes present in normal milk are not very efficient in preventing infection, because very small numbers of bacteria are able to induce infection experimentally. The mobilization of phagocytes from the blood to milk appears crucial in coping with the expansion of the bacterial population in the mammary gland. Important parameters for the outcome of mammary infections are the bactericidal efficiency of neutrophils and the antiphagocytic and cytotoxic properties of the invading bacteria, but several studies have shown that the promptness and the magnitude of the initial recruitment of neutrophils by the infected mammary gland have a profound influence on the severity and the outcome of mastitis. This is an incentive for studying the mechanisms behind the mobilization of neutrophils to the mammary gland. Although milk macrophages may play a role in the triggering of the inflammatory response, studies on several responses to infections at various epithelium sites strongly suggest that epithelial cells are capable of responding to bacterial intrusion and play a major part in the initiation of inflammation. A better knowledge of the effector cells and of the mediators involved in the mobilization of neutrophils could help in devising strategies to modulate this important determinant of milk quality and udder defense.
\end{abstract}

PMN / mastitis / dairy cattle / inflammation

\section{INTRODUCTION}

Concentrations of cells in milk, commonly termed somatic cell count (SCC), as opposed to bacterial cell count, have long been used as a marker of inflammation and an indicator of intramammary infection. The measurement of bulk milk SCC is a key factor in the assessment of the quality of herd milk and is used for milk payment and monitoring schemes of mastitis [1]. The proportion of neutrophils increases as milk SCC augments, and the two parameters are highly correlated [2]. Uninfected quarters secrete milk with low SCC, whereas infected quarters shed notable amounts of somatic cells. These amounts vary as a function of the pathogen involved: in a meta-analysis of papers published after 1971, the values of SCC (geometric means) were 68000 cells $\cdot \mathrm{mL}^{-1}$ for bacteriologically negative quarters, versus 333 000, 1129000,547 000, 1024 000, 4196000,155000 , and 164000 cells $\cdot \mathrm{mL}^{-1}$ for quarters infected by Staphylococcus aureus, Streptococcus agalactiae, Streptococcus dysgalactiae, Streptococcus uberis,

\footnotetext{
* Corresponding author: rainard@tours.inra.fr
} 
coliforms (Escherichia coli or Klebsiella spp.), coagulase-negative staphylococci, or Corynebacterium bovis, respectively [3].

In secretions of the healthy mammary gland, the predominant cell is the macrophage [4]. It is assumed that this "resident" cell population is beneficial to dairy cows, since milk macrophages are in principle capable of initiating the inflammatory response [5]. In milk of healthy quarters, neutrophils comprise 5 to $20 \%$ of the cell population $[4,6-8]$. The low concentration of neutrophils in the normal mammary gland might result from the existence of a permanent low grade attraction of PMN by the constitutive chemotactic activity found in the milk of healthy mammary glands [9]. Alternatively, the nursing or milking stimulus may be responsible for the presence of PMN in the milk of uninfected mammary glands [10]. This constant influx of PMN into normal sterile mammary glands may contribute to an immune surveillance. Following infection of the mammary gland, the early phase of the inflammatory response attracts large numbers of neutrophils from the blood into the milk. If the infective agent remains, this cellular infiltration, comprising initially about $95 \%$ of neutrophils, soon changes to one involving mononuclear cells ( $\mathrm{T}$ lymphocytes and monocytes), although neutrophils still comprise $70-80 \%$ of the cell population in chronic mastitis $[6,8,11,12]$.

The leucocytes present in normal milk are not very efficient in preventing infection from the most common mastitis pathogens, because very small numbers of bacteria are able to induce infection experimentally [13]. In practice, less than 100 colony-forming units (cfu) are enough, and the size of the inoculum seems to primarily modulate the duration of the lag period preceding the inflammatory response, not the severity of the disease: increasing the inoculum, in the range of 10 to 100000 (cfu) of mastitis pathogens such as Escherichia coli or Staphylococcus aureus, essentially shortens the lag period before infection manifests itself. Once they have penetrated the gland, bacteria multiply in the milk and reach concentrations between $10^{4}$ and $10^{6} \mathrm{cfu} \cdot \mathrm{mL}^{-1}$ before they elicit inflammation [14-16]. The growth of $E$. coli seems to be unrestricted in the milk in the first few hours after inoculation, with the in vivo doubling time close to $20 \mathrm{~min}$. The growth of staphylococci or streptococci may be much slower, but eventually the mobilization of phagocytes appears crucial to cope with the expansion of the bacterial population. Several studies have shown that the characteristics of the recruitment of PMN by the infected mammary gland, such as its promptness and its magnitude, have a profound influence on the severity and the outcome of mastitis, in relation with the antibacterial and the proinflammatory properties of PMN [17-19]. The mechanisms of the recruitment of PMN in the mammary gland are largely unknown, yet a better knowledge of the effector cells and the mediators involved could help in devising strategies to modulate this important parameter of milk quality and udder defense.

\section{THE CONTRIBUTION OF NEUTROPHILS TO THE DEFENSE OF THE UDDER}

\subsection{Neutrophils as the main effector cells against bacteria}

Several lines of evidence support a prominent role of neutrophils in the defense of the mammary gland, although most of them are only circumstantial.

A strong argument in favor of a prominent role of PMN is the effect of equine anti-bovine leukocyte serum (EABLS) administered by the intravenous route on the development of coliform bacteria (Klebsiella) or $S$. aureus mastitis [20,21]. Inoculation of the mammary glands with coliforms led to reduced inflammation in neutropenic cows compared to control animals, with much lower numbers of neutrophils in milk. 
Bacterial numbers reached billions per $\mathrm{mL}$ milk and necrosis of the mammary tissue developed. With $S$. aureus mastitis, chronic subclinical mastitis changed to gangrenous mastitis after EABLS administration. Gangrene was attributed to alpha-toxin secreted by the infecting $S$. aureus strain, through its vasoconstricting action. The disappearance of PMN from the milk was followed by uninhibited multiplication of $S$. aureus: concentrations more than 100 million cfu per $\mathrm{mL}$ were attained, compared to less than 500000 per $\mathrm{mL}$ before treatment. Necropsic examination of one cow showed that $S$. aureus had disseminated in the mammary tissue of all four quarters, as well as in distant organs like the brain and kidney. Administration of EABLS resulted in the disappearance of circulating PMN in a few hours, but monocytes were also affected, and lymphocyte numbers were halved at the peak of the response to the treatment. The authors concluded that continuous diapedesis of neutrophils into the milk in chronic staphylococcal mastitis protects the gland against the development of gangrenous mastitis in the presence of a strain of $S$. aureus capable of alphatoxin production [21].

Kinetic studies monitoring the concentrations of neutrophils and bacteria in milk often display slightly staggered saw-tooth patterns, reminiscent of prey and predator changes of population size [22]. High concentrations of PMN coincide with low concentrations of bacteria, and vice versa. This has been interpreted as resulting from a cause-and-effect link between bacteria and PMN numbers: bacteria multiply in milk, triggering an amplification of inflammation, which results in augmented recruitment of PMN. PMN entering the milk in high numbers reduce bacterial numbers. Then, "as the pathogen becomes less plentiful, the rate of leukocyte diapedesis into the milk decreases, leading in turn to the reactivation of bacterial multiplication and recidivation of the inflammatory process" [21]. Knowing the phagocytic and bactericidal abilities of PMN, this alternating see-saw pattern of bacterial and PMN numbers which occurs in the milk of an infected quarter strongly suggests that PMN control the multiplication of bacteria in milk.

The awareness that a pre-existing leucocytosis in milk could prevent the establishment of infection arose from the work of Schalm and colleagues [23, 24]. They showed that pre-existing infections or sterile inflammation preclude the development of infection following intramammary infusion of coliform bacteria or Streptococcus agalactiae, without clinical signs. This led to the notion of a PMN barrier to mastitis [25]. The contribution of macrophages to the cell barrier is likely to be only secondary, because they are outnumbered by PMN when such a barrier is present, and milk macrophages are less efficient than PMN for the killing of bacteria [26, 27], possibly in part because they lack myeloperoxidase [28]. Recognition of the effectiveness of a PMN barrier in preventing mammary infections has prompted research on how a permanent but mild inflammation could be beneficial to the udder health. Pre-existing infection of the udder by minor pathogens, such as Corynebacterium bovis or coagulasenegative staphylococci, has been shown to increase resistance to superinfection by common major pathogens [29-31]. This protection, not exclusively but to a large extent, is due to the elevated PMN concentration in milk [32].

The intentional use of a low-grade inflammatory stimulus has also been considered. Inserting a polyethylene intramammary device (IMD) (a plastic loop $2.0 \mathrm{~mm}$ in diameter and $115 \mathrm{~mm}$ long) into the cistern of the gland of cows increased the concentration of leucocytes in quarter foremilk and intensified the mobilization of PMN after intramammary infusion of $E$. coli endotoxin [33]. In another study, implantation of the intramammary device resulted in increased milk SCC in foremilk, strippings and residual milk to more than $10^{6}$ cells $\cdot \mathrm{mL}^{-1}$, but the $\mathrm{SCC}$ in total milk remained below $5 \times 10^{5}$ 
cells $\cdot \mathrm{mL}^{-1}$ [34]. Quarters fitted with the device showed a limited protection against naturally acquired and experimentally induced infections $[34,35]$. The intramammary device was considered to be incapable of stimulating a leukocytosis sufficient in stripping milk to prevent intramammary infection [36]. Roughening the IMD surface by abrasion intensified the recruitment of PMN: milk from quarters fitted with abraded IMD had significantly higher SCC than did milk from quarters implanted with smooth IMD [37]. This abraded IMD was associated with a better protection against experimental $E$. coli mastitis than did the smooth IMD [38].

The cellular barrier can be interpreted in two ways. In a static way, the cells present in the milk when bacteria make an intrusion are responsible for the protection. In a dynamic way, the cells already in the milk at the time of infection are mainly markers of inflammation, and the cells which are effectors of protection are those swiftly recruited by the amplification of the ongoing inflammation. The magnitude of the permanent inflammation necessary for protection, assessed through the concentration of somatic cells in milk, has been evaluated close to $6 \times 10^{5} \cdot \mathrm{mL}^{-1}$ milk [39] or less [32] when inflammation results from infection by minor pathogens, and protection by the IMD against the establishment of infection is associated with SCC greater than $5 \times 10^{5}$ cells $\cdot \mathrm{mL}^{-1}$ milk [38]. Such high SCC would be on the contrary to current practices in mastitis control and milk payment. Moreover, since milk yield is negatively affected by even a mild inflammation [40], such a light but permanent inflammation is likely to adversely affect the production of milk.

Severe clinical forms of mastitis have been shown to coincide with a reduced speed of mobilization of PMN. Failure of PMN mobilization in response to coliform infection of the mammary gland is often associated with severe local and systemic clinical signs, shock and ultimately death. This can occur in newly calved cows, and is associated with a delay in the appearance of PMN in the milk of infected quarters, whereas in the meantime bacteria reach concentrations of $10^{7} \mathrm{cfu} \cdot \mathrm{mL}^{-1}$ milk [41]. Some newly calved cows tend to be refractory to the presence of irritants, and the severity of the mastitis that follows infection with $E$. coli depends on the speed at which neutrophils are mobilized in the gland [17, $18]$.

A delayed appearance of PMN in the milk following infection correlates with high bacterial concentrations in the milk and severe mastitis. On the contrary, improved recruitment of PMN through immunisation reduces the severity of mastitis and augments the occurrence of bacteriological cure. Increasing the responsiveness of normal glands to infection is an alternative to establishing a permanent PMN barrier in milk. Studies in cattle indicate that it is possible to increase the rate and magnitude of PMN recruitment in response to specific antigens. PMN influx into milk occurs in response to ovalbumin in the udders of systemically immunized cows [42]. The specific recruitment of PMN can be obtained with a bacterial antigen such as the alpha hemolysin of $S$. aureus, and the influx of PMN results in the appearance of an efficient bactericidal activity in milk [43]. Immunization of cows with killed $E$. coli, or with a purified surface antigen of $S$. agalactiae, is followed by an increase of PMN influx in response to intramammary challenge with the corresponding pathogen, as compared to the response in unimmunized control cows. This stronger mobilization of PMN corresponded to lower bacterial counts in milk and to increased bacteriological cures [16, 44].

A relationship between the severity of clinical E. coli mastitis and the reactive oxygen species (ROS)-generating capacity of their blood neutrophils before infection has been reported [17, 45, 46]. Generation of ROS plays a part in the bactericidal capacity 
of PMN and a higher activity may thus contribute to reducing the bacterial load and the severity of the disease. The chemotactic ability of PMN before infection is also a predictor of the outcome of $E$. coli infection $[47,48]$. An increased incidence of clinical mastitis in high-producing cows may be related to the reduced phagocytic and chemotactic efficiency of neutrophils during hyperketonemia [49]. Overall, these studies indicate that preinfection PMN functional ability has an influence on the capacity of the cow to cope with the infection of the mammary gland.

Another indirect evidence of the protective role of PMN is the reported increased incidence of clinical mastitis in herds with a high proportion of cows with low SCC [50, 51]. The authors concluded that very low SCC during the udder inflammation-free state is associated with an increased risk of clinical mastitis. A very low number of leucocytes may reduce the responsiveness of the gland, by reducing its capacity to initiate the inflammatory response to the entry of pathogens.

\subsection{Neutrophils as inefficient phagocytes}

The dairy cow mobilizes billions of PMN to fight infection. Over 20 million neutrophils per $\mathrm{mL}$ of milk are commonly found in the milk of quarters inflicted with clinical mastitis. However, in spite of these numerous PMN, pathogenic bacteria can be recovered from milk for long periods. Chronic infections usually last several months [52], and during this time high concentrations $\left(>10^{6}\right.$ per $\left.\mathrm{mL}\right)$ of cells are present in milk [3, 52], concentrations which dwarf the concentrations of shedded bacteria, most often in the $10^{2}$ to $10^{4}$ per $\mathrm{mL}$ range. Also, severe E. coli mastitis develops in newly calved cows despite a massive mobilization of PMN in the infected gland [15]. The prolonged survival of bacteria confronted to high concentrations of PMN can be interpreted as resulting from the inefficiency of the phagocytic cells and casts doubt on the importance of the neutrophils as the main immune defense of the mammary gland. Several explanations can be put forward to explain why the PMN leucocytes, although they greatly outnumber mastitis pathogens in milk, are frequently unable to eliminate them from the mammary gland.

One of these reasons is that the phagocytic capacity of the neutrophils is reduced in the mammary gland [53]. Comparisons of the phagocytic ability of the PMN of milk with that of the PMN of blood showed that the number of bacteria killed by PMN isolated from milk is significantly less than the number killed by PMN isolated from the blood [54]. This reduced bactericidal activity is attributed to a deficiency of milk PMN to phagocytose and to kill intracellularly [53]. In this respect, it is noteworthy that the viability of PMN in milk is lower than in blood, is variable according to the stage of lactation and parity [55], and that aging PMN have reduced phagocytic abilities.

Milk lacks some of the compounds that favor the functions of PMN. Glucose is a limiting factor associated with a reduced phagocytosis of $S$. aureus by PMN in the milk [56]. Since milk PMN have reduced glycogen stores compared to blood PMN, this may limit the availability of energy. Another limiting factor in milk is oxygen, and the shortage of oxygen has been shown to impair the bactericidal capacity of PMN in milk, maybe through the reduced production of ROS [57]. It has been shown that milk PMN have reduced abilities to produce ROS, when compared to blood PMN, and this is likely to contribute to their decreased bactericidal activity [26, 28].

Other components of reduced availability in milk are opsonins. Phagocytic killing of bacteria by PMN is at its best when the pathogens are opsonized with antibodies $(\mathrm{Ab})$ or the $\mathrm{Ab}$ and complement. Most 
species and strains of bacteria isolated from clinical cases of mastitis are killed in milk when blood-derived PMN in excess of $10^{6}$ per $\mathrm{mL}$ are added [58]. However, opsonization may not be optimal: mastitic milk is superior to normal milk in supporting phagocytosis of Klebsiella organisms [59]. Addition of immune serum to skim milk, or use of milk of immunized cows, has been shown to improve phagocytosis of $S$. aureus $[60,61]$. Moreover, certain bacteria are more difficult to opsonize than are the average mastitis pathogens. Encapsulated E. coli resist to phagocytic engulfment after opsonization in normal milk, but are readily taken up by PMN in immune milk [62]. Mycoplasma are also not efficiently opsonized by normal milk, and need specific $\mathrm{Ab}$ to be ingested and killed by PMN [63, 64]. As to the complement, only the alternate pathway of activation is operating in normal milk, the amount of the $\mathrm{C} 3$ fragment that can be deposited on bacteria is limited, and mastitic milk is more efficient in this respect than is normal milk [65].

The reduced phagocytic efficiency also has been attributed to an interference from components in the milk. PMN in milk ingest fat globules, and these fat globules exert an inhibitory activity on phagocytosis $[53,66]$. In addition to reducing the ingestion of bacteria, fat globules also appear to interfere with the ability of PMN to kill phagocytosed staphylococci [67]. PMN in the milk also interact with casein micelles, which are seen associated with the cytoplasmic membrane and in internal phagosomes [54]. Casein exerts an inhibitory effect on both phagocytosis and bactericidal activity of PMN $[54,68]$. Casein in particular interferes with the oxygen radical generating pathway, depressing the oxydative burst which is one of the main bactericidal systems of the PMN [69].

Finally, virulence factors of bacteria may reduce the efficiency of phagocytic killing by PMN. Encapsulated bacteria are usually more resistant to phagocytosis than are unencapsulated bacteria. This is true of encapsulated E. coli [70], or of S. uberis, whose hyaluronic acid capsule has been shown to prevent phagocytosis by bovine PMN [71, 72]. Apart from antiphagocytic surface material, bacteria may target PMN with toxins which interfere with the phagocytic process. A special virulence factor may explain why the PMN barrier evoked by intramammary infusion of endotoxin is ineffective in preventing infection of the udder by mycoplasma [73]. Leukotoxins, which are exotoxins produced by many $S$. aureus strains isolated from mastitis, are able to kill bovine PMN, and consequently are likely to reduce the efficiency of the phagocytic defense during mastitis $[74,75]$.

Another argument against the protective role of PMN in milk is that higher milk cell counts in first lactation daughter groups are associated with a higher susceptibility to subclinical and clinical mastitis and subsequently to a higher mastitis prevalence with increasing age [76]. Also, a daughter group which showed a lower milk cell count during the first lactation was less susceptible to experimental mastitis than a group with a higher cell count [77]. The author concluded that these observations are incompatible with the generally accepted role of leucocytes in the defense of the mammary gland against infections.

\subsection{Important determinants of the efficiency of neutrophils in milk}

Considerable numbers of PMN are necessary to control the development of bacteria in the mammary gland, often with limited success since chronic infections proceed for months. This apparent inefficiency of the recruited PMN has been attributed to impaired PMN functions in milk, for the reasons stated above. Other circumstances intrinsic to the mammary gland may well contribute to complicate the task of the phagocytes. 
The concentration of PMN necessary to exert optimal bactericidal activity in milk seems to be around $2 \times 10^{6}$ cells $\cdot \mathrm{mL}^{-1}$, provided the cells are freshly recruited and correctly activated [43]. The results obtained both in vivo and in vitro indicate that the bactericidal efficiency increases up to this value, but does not improve much beyond. The risks of detrimental side effects, linked to the pro-inflammatory and enzymatic properties of PMN, increase at the very high concentrations that can be reached in the mammary gland $[53,78]$. This optimal concentration is close to the most efficient concentration of blood PMN when tested in vitro against bacteria such as $S$. aureus or E. coli [79]. Indeed, the rate of phagocytosis in vitro, when assayed in suspension in a liquid phase under constant agitation, depends on the bacteria-to-cell ratio, and on the concentration of both the bacteria and PMN. The incubation of $5 \times 10^{4} \mathrm{PMN} \cdot \mathrm{mL}^{-1}$ with bacteria suspensions of $10^{4}$ to $10^{6}$ per $\mathrm{mL}$ did not lead to any detectable decrease in the number of extracellular bacteria. About $5 \times 10^{5} \mathrm{PMN} \cdot \mathrm{mL}^{-1}$ are necessary to induce a significant decrease in bacterial number under these conditions. This is close to the concentration of PMN necessary in milk to constitute an effective cell barrier against new infections. That such a high concentration is necessary is not surprising if one considers that once PMN enter the milk, they are incapable of active and oriented locomotion and are consequently dependent on random collisions to bring them into contact with the bacteria. To be efficient, the random encounters necessitate high concentrations of PMN. Phagocytic efficiency will be proportional to the concentration of cells and will depend on liquid convection movements, which are also probably a limiting factor in the mammary gland. Neutrophils are more efficient at phagocytosing bacteria adhering to solid substrates than bacteria free in a liquid, and even the more so if the substrate comprises extracellular matrix, whose components possess activating properties for PMN primed previously by a chemotatic factor [80]. Phagocytosis of adherent bacteria, also termed surface phagocytosis, requires a lower degree of opsonization than phagocytosis in a liquid medium $[81,82]$, provided they receive a chemokinetic signal and are allowed to crawl freely on the solid substrate [83].

The concentration of bacteria in milk may not result exclusively from the phagocytic efficiency of milk PMN, depending on the type of infection. When bacteria develop mainly in milk, with little or no tissue colonization, as in most $E$. coli mastitis, phagocytic efficiency in the milk phase is determinant. When bacteria are able to adhere to and are internalized by epithelial cells, and can colonize the mammary tissue by establishing foci of infections, as occurs in $S$. aureus mastitis [84], phagocytosis in the milk phase is probably of secondary importance. There will be a continual shedding of bacteria from the foci of infection, and consequently low concentrations of bacteria may apparently persist concurrently with high milk concentrations of efficient PMN. Low numbers of planctonic bacteria released from these foci will need high concentrations of PMN to be prevented from multiplying and colonising new tissue sites.

Apart from the concentration of PMN in milk, another important parameter for the removal of infection is the efficiency of the recruited phagocytes. It has been shown that the antibacterial efficiency of milk PMN is not constant in quarters infected by $S$. aureus [22]. Both the phagocytic ability (ingestion) and the intracellular killing efficiency undergo tremendous variation (more than 1000 fold), being the lowest when SCC is low, and the highest at or near peak SCC [22]. It thus seems that maximal biological activation is attained when the recruitment of PMN is intense. PMN in milk quickly loose antibacterial capacity, because they ingest fat globules and casein, and also as a result of their short half-life. The mere influx of fresh PMN probably contributes to the apparent increase in PMN activity at the 
SCC peak. Activation of PMN is also likely to be related to the cytokines and chemokines which contributed to their recruitment. The intensity of the inflammatory signal, and maybe its nature, may influence the degree of activation of the recruited cells. PMN exist in one of three states: quiescent, primed, or active, and they are subject to regulation by cytokines which produce different levels of activation $[85,86]$. Enhancing the inflammatory response, in quarters infected by $S$. aureus, with either recombinant bovine interleukin 1 beta (rbIL-1b) or rbIL-2 resulted in different activation of the recruited PMN, thus confirming that different inflammatory stimuli lead to different degrees of activation of PMN in milk [87].

In conclusion, the literature search suggests that the balance is tipped in favor of a preeminent role of PMN in the protection of the mammary gland against bacterial infection, although PMN often cannot rid the mammary gland of the invading bacteria but just keep them at bay. Nevertheless, the efficiency of PMN is largely dependent on the infecting bacterial species. To overcome the phagocytic defense mobilized by the inflammatory response, bacteria which are successful parasites of the mammary gland must have evolved special adaptive mechanisms to cope with the bactericidal efficiency of these leucocytes. The PMN mobilized by the mammary gland are rather efficient against $E$. coli mastitis, fairly efficient against $S$. agalactiae and $S$. aureus mastitis, but much less efficient against $S$. uberis and Mycoplasma mastitis [73, 88]. Even in E. coli, S. agalactiae and $S$. aureus mastitis, PMN efficiency also seems to depend on the stage of infection. PMN are very efficient at the stage of the penetration of bacteria, and can constitute a barrier to infection. They are still efficient at the early phase of the inflammatory response, in the first few hours during which bacteria multiply in milk and progressively disseminate in the lumen of the gland. At this stage, bacterial numbers remain moderate (E. coli), and bacteria have not yet settled in the mammary tissue ( $S$. agalactiae,
S. aureus). Later, PMN are apparently much less efficient, for reasons which remain to be elucidated.

The efficiency of phagocytic defense at the early phase of infection has been documented by kinetic studies of experimentally induced infections. These studies indicate that there exists a lapse of time between the infusion of bacteria into the teat cistern and the appearance of PMN in milk. This delay is rather stereotyped in E. coli mastitis (it is mainly a function of the size of the inoculum), and very variable in length in $S$. aureus mastitis, but it always exists. The lag period of the inflammatory response has been shown to allow $E$. coli to multiply and reach concentrations in milk, which conditions the severity of the disease $[15,18]$. The lag period is also suspected to provide time for $S$. aureus to settle within the gland and to invade the interstitial tissue [84]. The shortening of the lag period following the traversing of the teat canal by bacteria could change the outcome of the infection, lessening the severity of clinical mastitis or augmenting the proportion of bacteriological cures. There are several observations supporting this assumption, obtained by immunisation with $S$. aureus, E. coli or S. agalactiae $[16,19,44]$. These observations reinforce the recognized importance of the swift and intense recruitment of PMN following the entry of bacteria in the lumen of the gland [58], and is an incentive for studying the mechanisms behind the mobilization of PMN to the mammary gland.

\section{MOBILIZATION OF NEUTROPHILS FROM THE BLOOD TO MILK}

\subsection{Model of migration from the blood to the lumen of a gland}

We only have a sketchy knowledge of the mechanisms of the migration of PMN from the blood to the milk in the mammary gland. The time of transit of neutrophils from the circulation to the milk is about $2 \mathrm{~h}$ 
after infusion of the teat cistern with endotoxin [89]. This represents the time required for the migratory signal to develop, plus the time for a neutrophil to adhere to the postcapillary venule endothelium, migrate between endothelial cells to exit the blood compartment, then crawl through the extracellular matrix of the mammary parenchyma, and, finally, traverse the epithelial lining of the teat cistern.

The journey which takes PMN from the blood to the milk includes the crossing of two barriers, one endothelial and the other epithelial, and the crossing of a conjunctive compartment including the basal lamina on which the intramammary epithelium rests. The influx of PMN into the milk supposes the implementation of a sequence of stimuli and responses whose spatial and temporal orchestration has yet to deliver its secrecies. Contrasting with the limited information on the inflammatory response of the mammary gland, the thorough study of human intestinal infections by salmonellas or colon bacilli enteropathogens, or of infections of the respiratory and the urinary tracts, has allowed the development of a model of relations between the pathogenic bacteria and the unspecific immune system of the mucous membranes [90]. This model may provide a framework for the events taking place during an intramammary infection.

The first event is the stimulation of epithelial cells by bacteria, either by direct contact (adherence) or via irritating metabolites or toxins. The epithelial cells react by synthesizing a chemokine, a molecule endowed with chemotactic properties for the PMN, and possibly for other leucocytes. It may be IL-8, the prototype of the chemokines active on PMN [91]. This chemokine is secreted in a polarized way, towards the basolateral face, but not towards the luminal compartment [92]. It imprints the subepithelial matrix, by carrying out a decreasing gradient up to the blood vessels [93]. This gradient is stabilized by the interactions of the chemokines with the proteoglycans abundant in the extracellular matrix of the conjunctive tissue. The endothelial cells of the venules react to this signal by expressing on their surface molecules for both anchoring and activation of the PMN [94]. Prompted to extravasate, the PMN follow the gradient of the chemokine up to the epithelium. There, they interact with the epithelial cells, and cross the tight junctions to finally reach the lumen.

This model endows the epithelial cells with a preeminent role in the initial recruitment of PMN, and considers these cells as effectors of non-specific immunity. It has been shown that respiratory or intestinal epithelial cells are able to synthetize a coordinated array of pro-inflammatory cytokines such as IL-6, TNF- $\alpha$ IL-8 and GM-CSF [95]. Knowledge is much less advanced in the case of the epithelial mammary cells, but it is known, however, that they can secrete IL-8 after stimulation by the $E$. coli endotoxin [96]. The epithelial cells, which are in first line, could thus start the inflammatory reaction very early after the penetration of the bacteria in milk.

The other population of cells in contact with the bacteria in the very first phases of the infection is that of the macrophages. After phagocytosis of bacteria, the macrophages of milk are able to secrete factors which are chemotactic for the PMN [5]. It is not known if these factors can cross an intact epithelium, or if they can carry out a gradient in the parenchyma only after deterioration of the epithelial barrier. Alternatively, they may operate by activating the epithelial cells, provided these cells possess on their apical face, receptors for the mediators released by macrophages. At all events, the capacity to secrete a whole range of inflammatory mediators, cytokines or components derived from arachidonic acid, confers to the macrophages a probably significant role of the sentinel of the mammary gland.

Another cellular type likely to play a significant role in PMN recruitment is the lymphocytes in intra- or sub-epithelial positions, 
cells whose number strongly increases during staphylococcic infections [97]. The characterization of these cells has not been undertaken, and they might be different from the lymphocytes which migrate into milk.

Finally, the PMN themselves are likely to participate in the development of inflammation, through a positive loop of regulation. Some results suggest that an increased concentration of PMN in the milk would not only be effective as a phagocytic barrier, but would also allow for a more rapid infiltration of PMN into the mammary gland after infection [98]. Also, the elevated SCC consecutive to IMD fitting is associated with amplification of the initial influx of PMN after injection of a low dose of $E$. coli endotoxin [33]. There is a possible direct role of PMN through the secretion of proinflammatory cytokines and chemokines [99], or indirectly through the amplification of a low-grade pre-existing inflammation. The content of PMN granules also contributes to the recruitment of leucocytes [100].

\subsection{Mediators of the recruitment of PMN to the mammary gland}

The bovine PMN are not or are only poorly attracted towards bacterial antigens (such as formyl-methionyl peptides) or by their metabolites (present in culture supernatants), on the contrary to the leucocytes of other species $[101,102]$. It thus should be supposed that inflammatory agents must be generated by the udder to initiate the migration of PMN.

The mediators responsible for the influx of PMN to milk were looked for either by infusing the potentially active agent by the teat canal and by measuring the induced inflammation, or by measuring the variations of concentrations in the milk of mediators known to be active in other circumstances, following experimental infections of the udder.
Inflammatory mediators like bradykinin, histamine and prostaglandins increase the vascular permeability, but in general do not induce an infiltration by PMN [103]. The histamine infusion through the teat canal causes an increase in the concentration of serum albumin in milk, but not an influx of PMN [100]. The concentrations of certain prostaglandins and leukotriene B4 (LTB4) increase during clinical mastitis, which lets one suppose a participation of these molecules in the exudation of blood protein in milk [104, 105]. LTB4, which is chemotactic for bovine PMN [106], does not cause a cellular reaction when it is infused in the udder [107].

Several cytokines are secreted by stimulated macrophages. Knowing that supernatants of the culture of mammary macrophages with opsonized staphylococci are chemotactic for PMN [5], one can naturally turn to the cytokines that this cellular type can secrete, in particular IL- $1 \beta$, TNF- $\alpha$, IL-8 and GM-CSF. The infusion of these cyto- kines through the teat canal causes a mobilization of neutrophils in milk [107, 108]. The maximum effect, comparable with that obtained with endotoxin, is obtained with IL-1 $\beta$. The stage of lactation is relevant to the activity: IL-8 and GM-CSF are active in the dry period, but not in a gland in lactation, whereas IL- $1 \beta$ and TNF- $\alpha$ are active whatever the physiological stage [108].

Another chemotactic factor likely to be generated in milk by the activation of the complement system, is the C5a fragment of the C5 component. Activated plasma (a source of C5a) or purified C5a is able to induce the recruitment of neutrophils in a dry udder, but not in an udder in lactation [107, 109]. The addition of unskimmed milk, but not of skimmed milk, to the source of C5a suppresses the cellular reaction, which suggests that in lactation, $\mathrm{C} 5 \mathrm{a}$ has its activity reduced by fat globules [109], although in vitro experiments have failed to show an inhibitory activity of fat globules against bovine C5a [110]. High concentrations of C5a 
are induced early in milk in cases of $E$. coli mastitis [111], but since it is often possible to generate only small quantities of C5a in normal milk [112], one can consider that C5a primarily has a role of amplification of the inflammatory reaction rather than of the initiation of the reaction.

It is remarkable that the cytokines which are the most effective in recruiting PMN in the milk do not have a direct chemotactic effect on these cells: IL- $1 \beta$ and TNF- $\alpha$ are able to induce the secretion of several cytokines among which are themselves (amplification) and IL-8. Many cellular types have receptors for these two cytokines and the induced answers are manyfold. By its action on the endothelial cells, IL-1 $\beta$ starts the diapedesis of PMN. It could seem paradoxical that these two pro-inflammatory cytokines are more active than factors endowed with a strong chemotactic capacity, such as IL-8 or C5a. This observation is in favor of a role of relay played by certain cells between the pro-inflammatory mediators generated in milk and the vascular compartment. The mammary epithelial cells seem clearly designated to fulfil this role. This function supposes the existence of receptors for these cytokines at the apical face of the epithelial cells, which remains to be established.

The relative inefficiency of chemoattractant molecules such as IL-8 or C5a when administered in the lumen of the gland during lactation may relate to the integrity of the epithelium. In lactation and at the very beginning of infection, the intact epithelial lining may preclude the passage of the chemoattractants, preventing them to initiate cell recruitment. During the dry period, or when infection has begun to develop, the epithelium may become leaky in places, and the chemoattractants may find their way up to the venules to trigger diapedesis of blood cells.

Significant quantities of pro-inflammatory cytokines (IL-1 $\beta$, TNF- $\alpha$, IL-6 and IL-8) are found in milk in experimental or natural
E. coli mastitis [15, 111-113]. IL-1 $\beta$ and TNF- $\alpha$ appear about at the same time as the first wave of cells, whereas the concentrations of IL-8 increase a little later. In all cases, it takes several hours after the penetration of the bacteria in the gland for the mediators to appear in the milk. The bacteria are then numerous in the milk, several tens of thousands per $\mathrm{mL}$. The fact that the cells appear in the milk at the same time or even slightly before the increases in concentrations of cytokines in the milk [111] suggests that the first signal of cellular recruitment lies elsewhere, since it takes up to two hours for the neutrophils to migrate from the blood to the milk. Perhaps the cytokines in milk would have as an essential role the stimulation of the phagocytic and bactericidal activities of the leucocytes. The recruited cells themselves could represent the major source of the cytokines in milk, since the leucocytes, PMN included, are good producers of IL- $1 \beta$, TNF- $\alpha$ and of IL-8 when they are stimulated by endotoxin [99], and mRNA of cytokines such as IL- $1 \beta$, TNF- $\alpha$, IL- 6 and IFN- $\gamma$ are found in milk inflammatory cells $[12,114]$.

In the case of infections by staphylococci, which do not release molecules as strongly activating the inflammatory response as endotoxin, the intensity of the inflammation is in general much more modest. In cases of subclinical infection by $S$. aureus, inflammatory cytokines (IL-1 $\beta$, TNF- $\alpha$, IL- 8 ) and C5a are usually not found in the milk at the beginning of the infection [115]. This supports the idea that the initial signals of cellular recruitment have their source at an epithelial or subepithelial position.

Several receptors on neutrophils participate in the migration from blood to milk. L-selectin (CD62L) plays a role in the first step of egress from the blood flow, permitting the initial neutrophil rolling on the endothelium, a prerequisite for endothelialdependent neutrophil arrest [116, 117] The $\beta_{2}$-integrins (CD11a,b,c/CD18) are also 
important cell surface adhesion molecules involved in neutrophil migration, as demonstrated by the impaired recruitment of neutrophils to infection sites in calves suffering from the genetic disease leukocyte adhesion deficiency (LAD), characterized by defects in the expression of $\beta_{2}$-integrins [118]. It has been shown in vitro that diapedesis through bovine mammary endothelial and mammary epithelial cells depends on $\beta_{2}$-integrin function [119]. Antibodies to CD18 inhibited the migration of bovine neutrophils through mammary endothelial and epithelial monolayers, and through a collagen type I matrix. Antibodies to CD11b had no effect on $\mathrm{C} 5 \mathrm{a}$ induced neutrophil migration through collagen, partially inhibited migration through the endothelial monolayer, and were as efficient as antibodies to CD18 to inhibit the migration through the epithelial monolayer. The endothelial receptor for neutrophil CD11b/CD18 (Mac-1, CR3) is likely to be the intercellular adhesion molecule ICAM-1, but the expression of these receptors on mammary epithelial cells remains to be documented.

The acute inflammatory reaction is primarily a manifestation of non-specific immunity. It has the advantage of starting in all the cases where the luminal compartment of the udder is invaded by bacteria, even if these bacteria had never caused infection before in the individual animal. Besides the unspecific inflammation, there are specific reactions which require a preliminary contact with the pathogen and the establishment of an immunologic memory, carried by the lymphocytes. These specific responses can be more intense and more efficient than the unspecific reactions.

\subsection{Antigen-specific recruitment of PMN}

Several studies highlight an increased cellular influx in milk in the hours following an infection when the cows were immunized beforehand with bacteria. This is true of the infections by mycoplasma [120], staphylococci $[19,121]$, streptococci [16] or E. coli [44]. A simple protein antigen like the egg albumin, which does not cause by itself any inflammatory reaction in naïve animals, induce an intense recruitment of PMN when it is introduced at a dose of a few $\mu \mathrm{g}$ through the teat canal of cows immunized beforehand by the subcutaneous route [42]. This reaction, which is induced by systemic immunization, is a local manifestation of a general phenomenon of sensitization to an antigen. It is also possible to obtain an intense recruitment of PMN by sensitizing cows with $\alpha$-toxin of $S$. aureus [43]. The intensity of the answer depends on the amount of antigen administered by the diathelic route and is accompanied by a transitory stimulation of the bactericidal activity of circulating PMN. When cows are immunized with a surface protein of Streptococcus agalactiae, the concentration of cells in milk is increased in the first hours following the infection (compared to non-immunized cows) and the bactericidal activity of whole milk (cells included) is also increased [16]. These results suggest that sensitizing with bacterial antigens could contribute to the elimination of the infection at an early stage.

The search of the mechanisms behind the immune recruitment of neutrophils gave rise to a few studies. In the guinea-pig, an intramammary PMN influx can be induced by immunization with egg albumin or tuberculin, and can be transferred by cells, but not by the serum of actively immunized animals $[122,123]$. Consequently, it is probable that neither the antibodies, nor the complement are responsible for the sensitization of the udder, and that it is a cell-mediated immune reaction.

In the cow, the concept of a cellular mediation of immune recruitment is reinforced by the absence of recruitment induced by the intramammary infusion of complexes of egg albumin-antibody, even when added with serum as a source of the complement [42]. Also, it is not possible to induce PMN 
recruitment by intramammary infusion of staphylococcic capsular polysaccharide in immunized animals, although they had elevated titres of antibody in milk against this antigen [43]. This observation discredits the participation of the antibodies in the phenomenon, but is in agreement with the contribution of memory lymphocytes since this polysaccharide is regarded as a thymo-independent antigen. In the mouse it was shown that lymphocytes $\mathrm{T} \mathrm{CD}^{+}$are necessary for the antigen-specific recruitment of the neutrophils to mycobacterial infection [124], and that these lymphocytes could act via chemotactic cytokines [125].

In conclusion, it is possible to increase the intensity of the recruitment of PMN by the mammary gland in response to a particular antigen, by local or systemic immunization, and all the observations are in favour of a mediation by the $\mathrm{T}$ lymphocytes. The more precise determination of the mechanisms responsible for antigen-specific recruitment of PMN should facilitate its optimization by vaccination.

\section{PROSPECTS \\ FOR THE ENHANCEMENT OF THE DEFENSE OF THE UDDER THROUGH THE RECRUITMENT OF PMN}

To stimulate the early recruitment of PMN, there is a possible way which exploits the genetic regulation of the acute inflammatory reaction. In the mouse, it is possible to select lines whose acute inflammatory reaction (Acute Inflammatory Response, AIR) is much more intense than that of the parental lines [126]. These AIRmax lines were obtained by selective breeding of mice which presented the strongest unspecific inflammatory reaction. The typing of the animals was carried out by subcutaneous injection of polyacrylamide beads, which do not induce neither humoral nor cellular immune responses. The progressive increase in the inflammatory reaction shows that the character "early recruitment of PMN" is controlled by several genes segregating independently, and whose effects are additive. The number of loci responsible for this polygenic regulation is estimated at 11 [127]. The heritability of the trait is rather high $\left(\mathrm{h}^{2}=0.26\right)$. The concept of a polygenic regulation with high heritability for the capacity of the organism to quickly mobilize high numbers of PMN at an infectious site with correlative resistance to a broad range of infections by pathogens, may be worth considering for the development of selection programs in the bovine species. Nevertheless, selection for increased responsiveness to infection, manifested by increased recruitment of PMN, could result in higher bulk milk cell counts and more clinical episodes of mastitis, even though infections might be eliminated more effectively [58]. The fact that AIRmax mice are more susceptible to an inflammatory disease like arthritis suggests that genetically increased PMN recruitment may be a double edged sword [128]. Moreover, the observation that cows with higher cell counts seem to be more susceptible rather than more resistant to mastitis discredits the use of a permanent cellular barrier [76, 77], and possibly the selection of cows who are able to massively recruit PMN. Indeed, since PMN are recruited more intensely in response to endotoxin in quarters with elevated SCC [33], increased susceptibility of cows with high SCC would mean that the augmented recruitment of PMN, independently of stimulated specific immunity, is ineffective in protecting the udder.

The other way of stimulating the recruitment of PMN is the immune-mediated reinforcement of the inflammatory response. Although the mechanisms underlying the antigen-specific recruitment of PMN are poorly understood, they do not rely on a permanently elevated SCC, and consequently are compatible with the mastitis control programs currently in use and with the selection of cows with low milk SCC. Intense recruitment of $\mathrm{PMN}$ is not sufficient per se to cope with pathogens. To exert their bactericidal potential, $\mathrm{PMN}$ require opsonins to 
recognize the bacteria, antitoxins to counter bacterial toxins, and a proper state of activation, provided by the cytokines and chemokines associated with the inflammatory and immune responses. Stimulated mobilization of PMN without opsonins and antitoxins would probably result in exacerbation of the severity of the disease, as it apparently occurs with $S$. uberis or mycoplasmal mastitis.

In conclusion, the recruitment of circulating PMN from the blood to milk is important for the defense of the mammary gland against bacterial infections, and the promptness of PMN mobilization can dramatically influence the outcome of infection. Nevertheless, milk is not a favourable medium for phagocytosis by PMN, and PMN can exert a deleterious effect on the inflamed tissue under certain circumstances. The mere consideration of the concentration of PMN is not sufficient to predict the outcome of infection and the resistance or susceptibility of the mammary gland to mastitis. Other parameters such as the activation state of the PMN, their intrinsic bactericidal activity, the presence of antibodies opsonizing the bacteria and neutralizing their toxins, have to be taken into account. Unraveling the mechanisms behind the recruitment of the PMN by the mammary tissue will be necessary to better understand how to modulate the mobilization of PMN at the advantage of the mammary gland and the preservation of its secretory function.

\section{REFERENCES}

[1] Bramley AJ. Mastitis: physiology or pathology. Flem Vet J 1991, 62 Suppl. 1: 3-11.

[2] Waite R, Blackburn PS. The chemical composition and the cell count of milk. J Dairy Res 1957, 24: 328-339.

[3] Djabri B, Bareille N, Beaudeau F, Seegers H. Quarter milk somatic cell count in infected dairy cows: a meta-analysis. Vet Res 2002, 33: 335-357.

[4] Lee CS, Wooding FB, Kemp P. Identification, properties, and differential counts of cell populations using electron microscopy of dry cows secretions, colostrum and milk from normal cows. J Dairy Res 1980, 47: 39-50.

[5] Craven N. Generation of neutrophil chemoattractants by phagocytosing bovine mammary macrophages. Res Vet Sci 1983, 35: 310-317.

[6] Concha C, Holmberg O, Astrom G. Cells found in non-infected and staphylococcus-infected bovine mammary quarters and their ability to phagocytose fluorescent microspheres. Zentralbl Veterinarmed B 1986, 33: 371-378.

[7] Miller RH, Paape MJ, Fulton LA. Variation in milk somatic cells of heifers at first calving. J Dairy Sci 1991, 74: 3782-3790.

[8] Sordillo LM, Shafer-Weaver K, DeRosa D. Immunobiology of the mammary gland. J Dairy Sci 1997, 80: 1851-1865.

[9] Manlongat N, Yang TJ, Hinckley LS, Bendel RB, Krider HM. Physiologic-chemoattractantinduced migration of polymorphonuclear leukocytes in milk. Clin Diagn Lab Immunol 1998, 5: 375-381.

[10] Paape MJ, Guidry AJ. Effect of milking on leukocytes in the subcutaneous abdominal vein of the cow. J Dairy Sci 1969, 52: 998-1002.

[11] Hill AW. Somatic cells - Friends of foes? Flem Vet J 1991, 62 Suppl 1: 217-232.

[12] Riollet C, Rainard P, Poutrel B. Cell subpopulations and cytokine expression in cow milk in response to chronic Staphylococcus aureus infection. J Dairy Sci 2001, 84: 1077-1084.

[13] Newbould FHS, Neave FK. The response of the bovine mammary gland to an infusion of staphylococci. J. Dairy Res 1965, 32: 163-170.

[14] Le Gall A, Plommet M. Observations sur la croissance des staphylocoques et la réaction leucocytaire au cours des premières heures de la mammite expérimentale de la brebis. Ann Biol Anim Biochim Biophys 1965, 5: 113-130.

[15] Shuster DE, Lee EK, Kehrli ME Jr. Bacterial growth, inflammatory cytokine production, and neutrophil recruitment during coliform mastitis in cows within ten days after calving, compared with cows at midlactation. Am J Vet Res 1996, 57: $1569-1575$.

[16] Rainard P, Lautrou Y, Sarradin P, Coulibaly A, Poutrel B. The kinetics of inflammation and phagocytosis during bovine mastitis induced by Streptococcus agalactiae bearing the protein X. Vet Res Commun 1991, 15: 163-176.

[17] Vandeputte-Van Messom G, Burvenich C, Roets E, Massart-Leen AM, Heyneman R, Kremer WD, Brand A. Classification of newly calved cows into moderate and severe responders to experimentally induced Escherichia coli mastitis. J Dairy Res 1993, 60: 19-29. 
[18] Hill AW. Factors influencing the outcome of Escherichia coli mastitis in the dairy cow. Res Vet Sci 1981, 31: 107-112.

[19] Colditz I, Watson D. Effect of immunisation on the early influx of neutrophils during staphylococcal mastitis in ewes. Res Vet Sci 1982, 33: 146-151.

[20] Jain NC, Schalm OW, Lasmanis J. Experimentally induced coliform (Aerobacter aerogenes) mastitis in normal cows and in cows made neutropenic by an equine anti-bovine leukocyte serum. Am J Vet Res 1971, 32: 19291935.

[21] Schalm OW, Lasmanis J, Jain NC. Conversion of chronic staphylococcal mastitis to acute gangrenous mastitis after neutropenia in blood and bone marrow produced by an equine anti-bovine leukocyte serum. Am J Vet Res 1976, 37 : 885-890.

[22] Daley MJ, Oldham ER, Williams TJ, Coyle PA. Quantitative and qualitative properties of host polymorphonuclear cells during experimentally induced Staphylococcus aureus mastitis in cows. Am J Vet Res 1991, 52: 474-479.

[23] Schalm OW, Lasmanis J, Carroll E. Effect of pre-existing leukocytosis on experimental coliform (Aerobacter aerogenes) mastitis in cattle. Am J Vet Res 1964, 25: 83-89.

[24] Schalm OW, Lasmanis J, Carroll EJ. Experimental Streptococcus agalactiae mastitis in cattle: attempts to superimpose the organism in lactating glands harboring unrelated bacterial infections and in glands with experimentally induced sterile inflammation. Am J Vet Res 1967, 28: 685-695.

[25] Schalm OW, Carroll EJ, Lasmanis J. The leukocyte barrier and serologic investigations of experimental coliform (Aerobacter aerogenes) mastitis in cattle. Am J Vet Res 1964, 25: 90-96.

[26] Dosogne H, Vangroenweghe F, Barrio B, Rainard P, Burvenich C. Decreased number and bactericidal activity against Staphylococcus aureus of the resident cells in milk of dairy cows during early lactation. J Dairy Res 2001, 68: 539-549.

[27] Sandgren CH, Nordling K, Bjork I. Isolation and phagocytic properties of neutrophils and other phagocytes from nonmastitic bovine milk. J Dairy Sci 1991, 74: 2965-2975.

[28] Mehrzad J, Dosogne H, Meyer E, Heyneman R, Burvenich C. Respiratory burst activity of blood and milk neutrophils in dairy cows during different stages of lactation. J Dairy Res 2001, 68: 399-415.

[29] Linde C, Holmberg O, Astrom G. The interference between coagulase negative staphylococci and Corynebacterium bovis and the common udder pathogens in the lactating cow. Nord Vet Med 1980, 32: 552-558.

[30] Bramley AJ. The effect of subclinical Staphylococcus epidermidis infection of the lactating bovine udder on its susceptibility to infection with Streptococcus agalactiae or Escherichia coli. $\mathrm{Br}$ Vet J 1978, 134: 146-151.

[31] Rainard P, Poutrel B. Effect of naturally occurring intramammary infections by minor pathogens on new infections by major pathogens in cattle. Am J Vet Res 1988, 49: 327-329.

[32] Poutrel B, Lerondelle C. Protective effect in the lactating bovine mammary gland induced by coagulase negative staphylococci against experimental Staphylococcus aureus infections. Ann Rech Vét 1980, 11: 327-332.

[33] Paape MJ, Wergin WP, Guidry AJ, Schultze WD. Phagocytic defense of the ruminant mammary gland. Adv Exp Med Biol 1981, 137: 555-578.

[34] Paape MJ, Schultze WD, Guidry AJ, Kortum WM, Weinland BT. Effect of an intramammary polyethylene device on the concentration of leukocytes and immunoglobulins in milk and on the leukocyte response to Escherichia coli endotoxin and challenge exposure with Staphylococcus aureus. Am J Vet Res 1981, 42: 774-783.

[35] Brooks BW, Barnum DA. The use of polyethylene intramammary device in protection of the lactating bovine udder against experimental infection with Staphylococcus aureus or Streptococcus agalactiae. Can J Comp Med 1982, 46: 267-269.

[36] Corlett NJ, Peters RR, Paape MJ, Schultze WD. Effect of intramammary device on new infection rate, milk yield, and milk somatic cell counts in Maryland dairy herds. J Dairy Sci 1984, 67: 2571-2579.

[37] Corlett NJ, Paape MJ, King RL. Effect of surface and composition of intramammary device on stripping milk somatic cell count. J Dairy Sci 1983, 66 (Suppl 1): 204-205.

[38] Bright SA, Schultze WD, Paape MJ, Peters RR. Effect of intramammary devices on the outcome of induced Escherichia coli infection of bovine mammary quarters. Am J Vet Res 1987, 48: 1290-1294.

[39] Postle DS, Roguinsky M, Poutrel B. Induced staphylococcal infections in the bovine mammary gland. Am J Vet Res 1978, 39: 29-35.

[40] Serieys F. Relation entre concentration cellulaire du lait individuel, production laitière, et sensibilité des vaches aux infections mammaires. Ann Rech Vet 1985, 16: 271-277.

[41] Hill AW, Shears AL, Hibbitt KG. The pathogenesis of experimental Escherichia coli mastitis 
in newly calved dairy cows. Res Vet Sci 1979, 26: 97-101.

[42] De Cueninck BJ. Immune-mediated inflammation in the lumen of the bovine mammary gland. Int Arch Allergy Appl Immunol 1979, 59: 394-402.

[43] Herbelin C, Poutrel B, Gilbert FB, Rainard P. Immune recruitment and bactericidal activity of neutrophils in milk of cows vaccinated with staphylococcal alpha-toxin. J Dairy Sci 1997 , 80: 2025-2034.

[44] Rainard P. Experimental mastitis with Escherichia coli: sequential response of leukocytes and opsonic activity in milk of immunised and unimmunised cows. Ann Rech Vet 1983, 14: 281-286.

[45] Heyneman R, Burvenich C, Vercauteren R. Interaction between the respiratory burst activity of neutrophil leukocytes and experimentally induced Escherichia coli mastitis in cows. J Dairy Sci 1990, 73: 985-994.

[46] Lohuis JA, Schukken YH, Henricks PA, Heyneman R, Burvenich C, Verheijden JH, Van Miert AS, Brand A. Preinfection functions of blood polymorphonuclear leukocytes and the outcome of experimental Escherichia coli mastitis in the cow. J Dairy Sci 1990, 73: 342-350.

[47] Kremer WD, Noordhuizen-Stassen EN, Grommers FJ, Daemen AJ, Henricks PA, Brand A, Burvenich C. Preinfection chemotactic response of blood polymorphonuclear leukocytes to predict severity of Escherichia coli mastitis. J Dairy Sci 1993, 76: 1568-1574.

[48] Van Werven T, Noordhuizen-Stassen EN, Daemen AJ, Schukken YH, Brand A, Burvenich C. Preinfection in vitro chemotaxis, phagocytosis, oxidative burst, and expression of CD11/CD18 receptors and their predictive capacity on the outcome of mastitis induced in dairy cows with Escherichia coli. J Dairy Sci 1997, 80: 67-74.

[49] Suriyasathaporn W, Heuer C, NoordhuizenStassen EN, Schukken YH. Hyperketonemia and the impairment of udder defense: a review. Vet Res 2000, 31: 397-412.

[50] Beaudeau F, Fourichon C, Seegers H, Bareille N. Risk of clinical mastitis in dairy herds with a high proportion of low individual milk somaticcell counts. Prev Vet Med 2002, 53: 43-54.

[51] Suriyasathaporn W, Schukken YH, Nielen M, Brand A. Low somatic cell count: a risk factor for subsequent clinical mastitis in a dairy herd. $\mathrm{J}$ Dairy Sci 2000, 83: 1248-1255.

[52] Rainard P, Poutrel B. Dynamics of nonclinical bovine intramammary infections with major and minor pathogens. Am J Vet Res 1982, 43: 2143-2146.
[53] Paape MJ, Wergin WP, Guidry AJ, Pearson RE. Leukocytes-second line of defense against invading mastitis pathogens. J Dairy Sci 1979, 62: 135-153.

[54] Russell MW, Reiter B. Phagocytic deficiency of bovine milk leucocytes: an effect of casein. J Reticuloendothel Soc 1975, 18: 1-13.

[55] Mehrzad J, Duchateau L, Pyorala S, Burvenich C. Blood and milk neutrophil chemiluminescence and viability in primiparous and pluriparous dairy cows during late pregnancy, around parturition and early lactation. J Dairy Sci 2002, 85: 3268-3276.

[56] Newbould FH. The effect of added serum and glucose, and some inherent factors, on phagocytosis in vitro by milk leukocytes from several cows. Can J Comp Med 1973, 37: 189-194.

[57] Goldberg JJ, Pankey JW, Politis I, Zavizion B, Bramley AJ. Effect of oxygen tension on killing of Escherichia coli by bovine polymorphonuclear neutrophil leucocytes in vitro. J Dairy Res 1995, 62: 331-338.

[58] Craven N, Williams MR. Defences of the bovine mammary gland against infection and prospects for their enhancement. Vet Immunol Immunopathol 1985, 10: 71-127.

[59] Jain NC, Lasmanis J. Phagocytosis of serum-resistant and serum-sensitive coliform bacteria (Klebsiella) by bovine neutrophils from blood and mastitic milk. Am J Vet Res 1978, 39: 425-427.

[60] Newbould FH. Enhancement of phagocytosis in bovine milk leukocytes in vitro. Can J Comp Med 1970, 34: 261-264.

[61] Guidry AJ, Paape MJ, Pearson RE, Williams WF. Effect of local immunization of the mammary gland on phagocytosis and intracellular kill of Staphylococcus aureus by polymorphonuclear neutrophils. Am J Vet Res 1980, 41: 1427-1431.

[62] Hill AW, Heneghan DJ, Field TR, Williams MR. Increase in specific opsonic activity in bovine milk following experimental Escherichia coli mastitis. Res Vet Sci 1983, 35: 222-226.

[63] Jain NC, Jasper DE, Dellinger JD. Experimental bovine mastitis due to mycoplasma. Cornell Vet 1969, 59: 10-28.

[64] Howard CJ, Taylor G, Collins J, Gourlay RN. Interaction of Mycoplasma dispar and Mycoplasma agalactiae subsp. bovis with bovine alveolar macrophages and bovine lacteal polymorphonuclear leukocytes. Infect Immun 1976, 14: 11-17.

[65] Rainard P, Poutrel B. Deposition of complement components on Streptococcus agalactiae in bovine milk in the absence of inflammation. Infect Immun 1995, 63: 3422-3427. 
[66] Paape MJ, Guidry AJ, Kirk ST, Bolt DJ. Measurement of phagocytosis of 32P-labeled Staphylococcus aureus by bovine leukocytes: lysostaphin digestion and inhibitory effect of cream. Am J Vet Res 1975, 36: 1737-1743.

[67] Paape MJ, Guidry AJ. Effect of fat and casein on intracellular killing of Staphylococcus aureus by milk leukocytes. Proc Soc Exp Biol Med 1977, 155: 588-593.

[68] Russell MW, Brooker BE, Reiter B. Inhibition of the bactericidal activity of bovine polymorphonuclear leucocytes and related systems by casein. Res Vet Sci 1976, 20: 30-35.

[69] Cooray R. Casein effects on the myeloperoxidase-mediated oxygen-dependent bactericidal activity of bovine neutrophils. Vet Immunol Immunopathol 1996, 51: 55-65.

[70] Hill AW, Heneghan DJ, Williams MR. The opsonic activity of bovine milk whey for the phagocytosis and killing by neutrophils of encapsulated and non-encapsulated Escherichia coli. Vet Microbiol 1983, 8: 293-300.

[71] Leigh JA, Field TR. Killing of Streptococcus uberis by bovine neutrophils following growth in chemically defined media. Vet Res Commun 1991, 15: 1-6.

[72] Ward PN, Field TR, Ditcham WG, Maguin E, Leigh JA. Identification and disruption of two discrete loci encoding hyaluronic acid capsule biosynthesis genes has A, hasB, and hasC in Streptococcus uberis. Infect Immun 2001, 69: 392-399.

[73] Brownlie J, Howard CJ, Gourlay RN. The effect of an intramammary infusion of endotoxin on experimentally induced mycoplasmal mastitis. J Hyg (Lond) 1979, 83: 501-505.

[74] Schuberth HJ, Krueger C, Zerbe H, Bleckmann E, Leibold W. Characterization of leukocytotoxic and superantigen-like factors produced by Staphylococcus aureus isolates from milk of cows with mastitis. Vet Microbiol 2001, 82: 187-199.

[75] Loeffler DA, Schat KA, Norcross NL. Use of $51 \mathrm{Cr}$ release to measure the cytotoxic effects of staphylococcal leukocidin and toxin neutralization on bovine leukocytes. J Clin Microbiol 1986, 23: 416-420.

[76] Grootenhuis G. Mastitis prevention by selection of sires. Vet Rec 1981, 108: 258-260.

[77] Grootenhuis G. The difference in hereditary susceptibility to three mastitis agents between two daughter groups. Tijdschr Diergeneeskd 1976, 101: 779-786.

[78] Smith JA. Neutrophils, host defense, and inflammation: a double-edged sword. J Leukoc Biol 1994, 56: 672-686.

[79] Leijh PC, van den Barselaar MT, van Zwet TL, Dubbeldeman-Rempt I, van Furth R. Kinetics of phagocytosis of Staphylococcus aureus and Escherichia coli by human granulocytes. Immunology 1979, 37: 453-465.

[80] Brown EJ. The role of extracellular matrix proteins in the control of phagocytosis. J Leukoc Biol 1986, 39: 579-591.

[81] Lee DA, Hoidal JR, Clawson CC, Quie PG, Peterson PK. Phagocytosis by polymorphonuclear leukocytes of Staphylococcus aureus and Pseudomonas aeruginosa adherent to plastic, agar, or glass. J Immunol Methods 1983, 63: 103-114.

[82] Rainard P. Assessment by a fluorochrome microassay of phagocytic killing of group B streptococci adherent to glass. J Immunol Methods 1986, 94: 113-118.

[83] Rainard P. Involvement of locomotion of granulocytes in the phagocytosis of glass-adherent group B streptococci in the absence of opsonins. FEMS Microbiol Lett 1988, 49: 309-315.

[84] Hensen SM, Pavicic MJ, Lohuis JA, de Hoog JA, Poutrel B. Location of Staphylococcus aureus within the experimentally infected bovine udder and the expression of capsular polysaccharide type 5 in situ. J Dairy Sci 2000, 83: 1966-1975.

[85] Hallett MB, Lloyds D. Neutrophil priming: the cellular signals that say 'amber' but not 'green'. Immunol Today 1995, 16: 264-268.

[86] Steinbeck MJ, Roth JA. Neutrophil activation by recombinant cytokines. Rev Infect Dis 1989, 11: 549-568.

[87] Daley MJ, Coyle PA, Williams TJ, Furda G, Dougherty R, Hayes PW. Staphylococcus aureus mastitis: pathogenesis and treatment with bovine interleukin-1 beta and interleukin-2. J Dairy Sci 1991, 74: 4413-4424.

[88] Leigh JA, Field TR. Streptococcus uberis resists the bactericidal action of bovine neutrophils despite the presence of bound immunoglobulin. Infect Immun 1994, 62: 1854-1859.

[89] Persson K, Sandgren CH, Rodriguez-Martinez $\mathrm{H}$. Studies of endotoxin-induced neutrophil migration in bovine teat tissues, using indium-111labeled neutrophils and biopsies. Am J Vet Res 1992, 53: 2235-2240

[90] McCormick B, Gewirtz AT, Madara JL. Epithelial crosstalk with bacteria and immune cells. Curr Opin Gastroenterol 1998, 14: 492-497.

[91] Eckmann L, Kagnoff MF, Fierer J. Epithelial cells secrete the chemokine interleukin- 8 in response to bacterial entry. Infect Immun 1993, 61: 4569-4574.

[92] McCormick BA, Colgan SP, Delp-Archer C, Miller SI, Madara JL. Salmonella typhimurium attachment to human intestinal epithelial monolayers: transcellular signalling to subepithelial neutrophils. J Cell Biol 1993, 123: 895-907.

[93] McCormick BA, Hofman PM, Kim J, Carnes DK, Miller SI, Madara JL. Surface attachment of 
Salmonella typhimurium to intestinal epithelia imprints the subepithelial matrix with gradients chemotactic for neutrophils. J Cell Biol 1995, 131: 1599-1608.

[94] Hogg N. A model of leukocyte adhesion to vascular endothelium. Curr Top Microbiol Immunol 1993, 184: 79-86.

[95] Jung HC, Eckmann L, Yang SK, Panja A, Fierer J, Morzycka-Wroblewska E, Kagnoff MF. A distinct array of proinflammatory cytokines is expressed in human colon epithelial cells in response to bacterial invasion. J Clin Invest 1995, 95: 55-65.

[96] Boudjellab N, Chan-Tang HS, Li X, Zhao X. Interleukin 8 response by bovine mammary epithelial cells to lipopolysaccharide stimulation. Am J Vet Res 1998, 59: 1563-1567.

[97] Nickerson SC, Heald CW. Cells in local reaction to experimental Staphylococcus aureus infection in bovine mammary gland. J Dairy Sci 1982, 65: 105-116.

[98] Jain NC, Schalm OW, Carroll EJ, Lasmanis J. Experimental mastitis in leukopenic cows: immunologically induced neutropenia and response to intramammary inoculation of Aerobacter aerogenes. Am J Vet Res 1968, 29: 2089-2097.

[99] Cassatella MA. The production of cytokines by polymorphonuclear neutrophils. Immunol Today 1995, 16: 21-26.

[100] Jain NC, Schalm OW, Carroll EJ, Lasmanis J. Leukocytes and tissue factors in the pathogenesis of bovine mastitis. Am J Vet Res 1972, 33: 1137-1145.

[101] Carroll EJ, Mueller R, Panico L. Chemotactic factors for bovine leukocytes. Am J Vet Res 1982, 43: 1661-1664.

[102] Gray GD, Knight KA, Nelson RD, Herron MJ. Chemotactic requirements of bovine leukocytes. Am J Vet Res 1982, 43: 757-759.

[103] Issekutz AC. Effect of vasoactive agents on polymorphonuclear leukocyte emigration in vivo. Lab Invest 1981, 45: 234-240.

[104] Giri SN, Chen Z, Carroll EJ, Mueller R, Schiedt MJ, Panico L. Role of prostaglandins in pathogenesis of bovine mastitis induced by Escherichia coli endotoxin. Am J Vet Res 1984, 45: 586-591.

[105] Rose DM, Giri SN, Wood SJ, Cullor JS. Role of leukotriene B4 in the pathogenesis of Klebsiella pneumoniae-induced bovine mastitis. Am J Vet Res 1989, 50: 915-918.

[106] Craven N. Chemotactic factors for bovine neutrophils in relation to mastitis. Comp Immunol Microbiol Infect Dis 1986, 9: 29-36.

[107] Persson K, Larsson I, Hallen SC. Effects of certain inflammatory mediators on bovine neutrophil migration in vivo and in vitro. Vet Immunol Immunopathol 1993, 37: 99-112.

[108] Persson K, Colditz IG, Flapper P, Franklin NA, Seow HF. Cytokine-induced inflammation in the ovine teat and udder. Vet Immunol Immunopathol 1996, 53: 73-85.

[109] Colditz IG, Maas PJ. The inflammatory activity of activated complement in ovine and bovine mammary glands. Immunol Cell Biol 1987, 65: 433-436.

[110] Rainard P. Bovine milk fat globules do not inhibit C5a chemotactic activity. Vet Res 2002, 33: 413-419.

[111] Shuster DE, Kehrli ME Jr, Rainard P, Paape M. Complement fragment $\mathrm{C} 5 \mathrm{a}$ and inflammatory cytokines in neutrophil recruitment during intramammary infection with Escherichia coli. Infect Immun 1997, 65: 3286-3292.

[112] Rainard P, Sarradin P, Paape MJ, Poutrel B. Quantification of $\mathrm{C} 5 \mathrm{a} / \mathrm{C} 5 \mathrm{a}$ (desArg) in bovine plasma, serum and milk. Vet Res 1998, 29: 73-88.

[113] Hisaeda K, Hagiwara K, Eguchi J, Yamanaka H, Kirisawa R, Iwai H. Interferon-gamma and tumor necrosis factor-alpha levels in sera and whey of cattle with naturally occurring coliform mastitis. J Vet Med Sci 2001, 63: 1009-1011.

[114] Taylor BC, Keefe RG, Dellinger JD, Nakamura Y, Cullor JS, Stott JL. T cell populations and cytokine expression in milk derived from normal and bacteria-infected bovine mammary glands. Cell Immunol 1997, 182: 68-76.

[115] Riollet C, Rainard P, Poutrel B. Differential induction of complement fragment $\mathrm{C} 5 \mathrm{a}$ and inflammatory cytokines during intramammary infections with Escherichia coli and Staphylococcus aureus. Clin Diagn Lab Immunol 2000, 7: 161-167.

[116] Bargatze RF, Kurk S, Butcher EC, Jutila MA. Neutrophils roll on adherent neutrophils bound to cytokine-induced endothelial cells via Lselectin on the rolling cells. J Exp Med 1994, 180: 1785-1792.

[117] Jutila MA, Rott L, Berg EL, Butcher EC. Function and regulation of the neutrophil MEL-14 antigen in vivo: comparison with LFA-1 and MAC1. J Immunol 1989, 143: 3318-3324.

[118] Kehrli ME Jr, Schmalstieg FC, Anderson DC, Van der Maaten MJ, Hughes BJ, Ackermann MR, Wilhelmsen CL, Brown GB, Stevens MG, Whetstone CA. Molecular definition of the bovine granulocytopathy syndrome: identification of deficiency of the Mac-1 (CD11b/CD18) glycoprotein. Am J Vet Res 1990, 51: 1826-1836.

[119] Smits E, Burvenich C, Guidry AJ, Massart-Leen A. Adhesion receptor CD11b/CD18 contributes to neutrophil diapedesis across the bovine 
blood-milk barrier. Vet Immunol Immunopathol 2000, 73: 255-265.

[120] Gourlay RN, Howard CJ, Brownlie J. Localized immunity in experimental bovine mastitis caused by Mycoplasma dispar. Infect Immun 1975, 12: 947-950.

[121] Targowski SP, Berman DT. Leukocytic response of bovine mammary gland to injection of killed cells and cell walls of Staphylococcus aureus. Am J Vet Res 1975, 36: 1561-1565.

[122] De Cueninck BJ. Expression of cell-mediated hypersensitivity in the lumen of the mammary gland in guinea pigs. Am J Vet Res 1982, 43: 1696-1700.

[123] Targowski SP, Nonnecke BJ. Cell-mediated immune response of the mammary gland in guniea pigs. I. Effect of antigen injection into the vaccinated and unvaccinated glands. Am J Reprod Immunol 1982, 2: 29-38.

[124] Appelberg R. CD4 ${ }^{+}$T cells are required for antigen-specific recruitment of neutrophils by BCGimmune spleen cells. Immunology 1992, 75: 414-419.
[125] Appelberg R. Mycobacterial infection primes T cells and macrophages for enhanced recruitment of neutrophils. J Leukoc Biol 1992, 51: 472477.

[126] Ibanez OM, Stiffel C, Ribeiro OG, Cabrera WK, Massa S, De Franco M, Sant'anna OA, Decreusefond C, Mouton D, Siqueira M. Genetics of nonspecific immunity. I. Bidirectional selective breeding of lines of mice endowed with maximal or minimal inflammatory responsiveness. Eur J Immunol 1992, 22: 2555-2563.

[127] Araujo LM, Ribeiro OG, Siqueira M, De Franco M, Starobinas N, Massa S, Cabrera WH, Mouton D, Seman M, Ibanez OM. Innate resistance to infection by intracellular bacterial pathogens differs in mice selected for maximal or minimal acute inflammatory response. Eur J Immunol 1998, 28: 2913-2920.

[128] Vigar ND, Cabrera WH, Araujo LM, Ribeiro OG, Ogata TR, Siqueira M, Ibanez OM, De Franco M. Pristane-induced arthritis in mice selected for maximal or minimal acute inflammatory reaction. Eur J Immunol 2000, 30: 431-437. 